\title{
Seasonal Changes in Serum Calcium and $17 \beta$-Estradiol Levels in Persian Sturgeon, Acipenser persicus
}

Mahboubeh Hosseinzadeh, Mohammad Reza Imanpoor, Ali Shabani and Hamed Nekoubin*

Department of Fishery, Gorgan University of Agricultural Sciences and Natural Resources, Gorgan, Iran

\begin{abstract}
Concentrations of total serum calcium and17 $\beta$-estradiol (E2) were measured during four stages of ovarian growth in Persian sturgeon, Acipenser persicus. Total calcium and E2 increased from stage II (cortical alveolus) and reached their highest levels $(6.67 \pm 1.15 \mathrm{mg} / \mathrm{dl}$ and $5.33 \pm 1.06 \mathrm{ng} / \mathrm{ml}$, respectively) during stage III (vitellogenic). Levels of both total calcium and E2 decrease during stage IV (ripe). A decline in serum calcium level was observed postspawning (stage $V)$. Total serum calcium exhibited a linear relationship $(r 2=0.6789)$ with plasma $E 2(P<0.01)$. Both E2 and total serum calcium can be utilized to identify mature vitellogenic (stage III) females in sturgeon broodstocks.
\end{abstract}

Keywords: Persian sturgeon; Calcium; 17 $\beta$-estradiol; Gonadal maturation

\section{Introduction}

The Persian sturgeon, Acipenser persicus, is an endangered species the southern part of Caspian Sea, especially along the shores of Iran $[1,2]$. During the few past decades many attempts have been made to augment their stocks in terms of supportive breeding in Iran. Successful management of sturgeon populations requires knowledge of the stock composition with regard to sex and maturational status [3]. One of the problems in sturgeon broodstock is the slow and asynchronous ovarian maturation [4].

Plasma sex steroid, vitellogenin (VTG, an egg protein precursor), and calcium profiles have provided valuable insights in to the reproductive cycles of sturgeon populations $[5,6]$.

The VTG particle is phosphorylated, lipidated, and glycosylated, and serves as a major supply of minerals such as calcium, magnesium, zinc, and iron to the oocyte, and therefore to the developing embryo. The increase in plasma protein, calcium, magnesium, and phosphoprotein content can be used as indicators of plasma VTG levels $[7,8]$.

Vitellogenesis by the liver is stimulated and maintained by E2 and is accompanied by increased plasma calcium and phosphate levels [9]. Exogenous estrogen increases serum calcium concentrations in female goldfish [10], Fundulus kansae [11], and salmonids [12]. Others examined effects of E2 exposure on the distribution of plasma calcium, magnesium, inorganic phosphate, and plasma protein in rainbow trout, and reported that both plasma calcium and total plasma protein increased in a dose dependent manner following exposure to E2 [13]. An early study on Atlantic cod used plasma calcium as an index of estrogenic activity in females [14]. Concomitant increases in plasma calcium and VTG concentration following estrogenic stimulation have been reported previously in salmonid fish [15].

Serum sex steroid and calcium concentrations have not previously been applied to investigate the reproductive cycle of Persian sturgeon. Therefore, we investigated relationships between serum E2 and serum total calcium in Persian sturgeon female during the natural reproductive cycle.

\section{Materials and Methods}

\section{Fish collection}

Fish collection was conducted seasonally between May 2011 and May 2012. Thirty-five specimens of female Persian sturgeon ( $A$. persicus) were captured in gillnets from the southeastern Caspian Sea. The captured fishes in late winter and early spring that were in stage IIIIV or IV transferred to Shahid Marjani sturgeon Propagation Center in Gorgan, Iran. Two injections of sturgeon pituitary preparation (PP) (3-5 $\mathrm{mg} / \mathrm{kg}$ ) were used to simulate final maturation. The first PP injection (5\% of total dose) was made at $10 \mathrm{PM}$ and second (95\% of total dose) $12 \mathrm{~h}$ later at $8 \mathrm{AM}$ and blood samples were taken from caudal vein with a non heparinized syringe $24 \mathrm{~h}$ after second injection.

\section{Determination of sexual maturity stages}

Each sturgeon was weighed and fork length measured. The gonad samples of females during each season were fixed in Bouin's fluid for $48 \mathrm{~h}$ and then transferred to $70 \%$ ethanol for storage until processing for light microscopy. Paraffin sections of 4-7 $\mu \mathrm{m}$ thickness were stained with hematoxylin and eosin. The developmental stages of gonads were classified according to the system of Amiri et al. [16].

\section{Serum 17 $\beta$-estradiol and calcium Analyses}

Blood samples were centrifuged for $10 \mathrm{~min}$. at $3000 \times \mathrm{g}$. The serum was removed and placed into a clean microcentrifuge tube and stored at $-20^{\circ} \mathrm{C}$ until analyzed.

Serum E2 was measured by Enzyme-Linked Immune Sorbent Assay (ELISA) according to the procedure of Semenkova et al. [17]. Commercial kits for measurement of E2 levels in the sturgeon serum were obtained from Tehran, Iran.

Total serum calcium concentrations were measured for each female Persian sturgeon using a spectrophotometer (Model wap-S2000-UV/ VIS, Cambridge-UK).

*Corresponding author: Hamed Nekoubin, Department of Fishery, Gorgan University of Agricultural Sciences and Natural Resources, Gorgan, Iran, E-mail: M. Hoseinzade89@gmail.com

Received August 18, 2012; Accepted November 06, 2012; Published Novembe 16,2012

Citation: Hosseinzadeh M, Imanpoor MR, Shabani A, Nekoubin H (2013) Seasonal Changes in Serum Calcium and 17ß-Estradiol Levels in Persian Sturgeon, Acipenser persicus. J Aquac Res Development 4:159 doi:10.4172/21559546.1000159

Copyright: () 2013 Hosseinzadeh M, et al. This is an open-access article distributed under the terms of the Creative Commons Attribution License, which permits unrestricted use, distribution, and reproduction in any medium, provided the original author and source are credited. 
Citation: Hosseinzadeh M, Imanpoor MR, Shabani A, Nekoubin H (2013) Seasonal Changes in Serum Calcium and 17ß-Estradiol Levels in Persian Sturgeon, Acipenser persicus. J Aquac Res Development 4:159 doi:10.4172/2155-9546.1000159

\section{Data analysis}

Distribution parameters are presented as means and Standard Deviation (SD). Serum E2 and calcium concentrations were compared by the one-way Analysis of Variance (ANOVA) and Duncan's test. Assignment of data correlation was done by Pearson tests, and the relationships between total plasma calcium and E2 were evaluated by linear regression. The accepted statistical significance level was $\mathrm{P}<0.05$.

\section{Results}

The ovary stages of Persian sturgeon are summarized in table 1. Total calcium and E2 increased and reached their highest levels in stage III (Table 2).

There was significant differences in mean plasma E2 concentration among reproductive stages (Figure $1, \mathrm{P}<0.05$ ). Immature (stage II) female captured in autumn 2011, had a significantly lower mean E2 $(0.78 \pm 0.1 \mathrm{ng} / \mathrm{ml} \mathrm{E} 2)$ than all other stages $(\mathrm{P}<0.05)$. Stage III had significantly higher serum E2 concentration compared to other stages. Serum E2 decreases during late winter and early spring in stage IV and $\mathrm{V}$ females (Figures 1 and 2). There was no significant difference in levels of $\mathrm{E} 2$ between stages IV and V $(\mathrm{P}>0.05)$.

Mean calcium concentrations had a similar pattern to mean E2 concentrations (Figure 1). The highest concentration of calcium was observed in stage III females $(6.67 \pm 1.15 \mathrm{mg} / \mathrm{dl})$. Lowest serum levels

\begin{tabular}{|c|c|}
\hline Ovary stage & Characteristics \\
\hline Cortical alveoli stage (II) & $\begin{array}{l}\text { In this stage oocytes in the ovaries appear to } \\
\text { contain oil droplets. }\end{array}$ \\
\hline Vitellogenic (yolk) stage (III) & $\begin{array}{c}\text { Yolk granules were visible as a ring of deep } \\
\text { eosinophilic inclusions in the cytoplasm and later } \\
\text { incorporated the whole cytoplasmic area. The zona } \\
\text { radiata was clearly visible. }\end{array}$ \\
\hline Ripe (mature) stage (IV) & $\begin{array}{l}\text { The oocyte has become larger and more hydrated, } \\
\text { and the nucleus has migrated toward the periphery } \\
\text { and is in the process of dissolution. }\end{array}$ \\
\hline Ovulation stage (V) & $\begin{array}{c}\text { During ovulation the oocytes detach from the follicle } \\
\text { cells. }\end{array}$ \\
\hline
\end{tabular}

Table 1: Ovary stages of $A$. persicus.

\begin{tabular}{|c|c|c|c|}
\hline Category & $\mathbf{n}$ & Calcium (mg/dl) & E2 (ng/ml) \\
\hline Cortical alveoli stage (II) & 7 & $0.29 \pm 0.12^{\mathrm{c}}$ & $0.78 \pm 0.10^{\mathrm{c}}$ \\
\hline Vitellogenic stage (III) & 6 & $6.67 \pm 1.15^{\mathrm{a}}$ & $5.33 \pm 1.06^{\mathrm{a}}$ \\
\hline Ripe (mature) stage (IV) & 14 & $2.86 \pm 0.78^{\mathrm{b}}$ & $1.98 \pm 0.48^{\mathrm{b}}$ \\
\hline Ovulation stage (V) & 8 & $0.07 \pm 0.05^{\mathrm{c}}$ & $2.31 \pm 0.35^{\mathrm{b}}$ \\
\hline
\end{tabular}

Values with different superscript letters denote significantly different means within each column $(P<0.05)$

Table 2: Calcium and $17 \beta$-estradiol (E2) concentrations in serum (mean \pm SD) of Persian sturgeon.

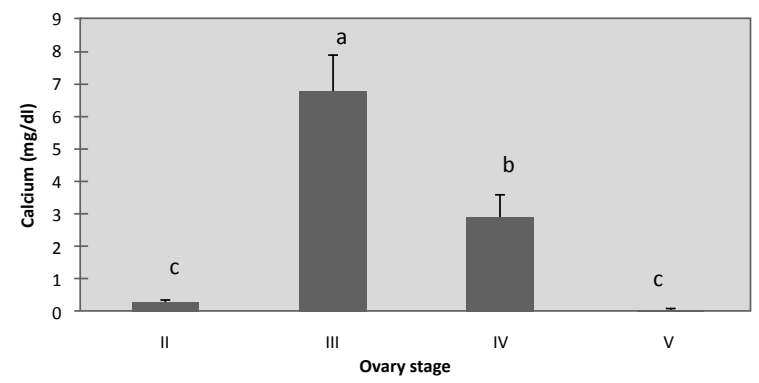

Figure 1: Changes in serum calcium levels by ovary stage of Persian sturgeon Each value is mean $\pm S D$. Means with different letter subscripts are significantly different $(\mathrm{P}<0.05)$.

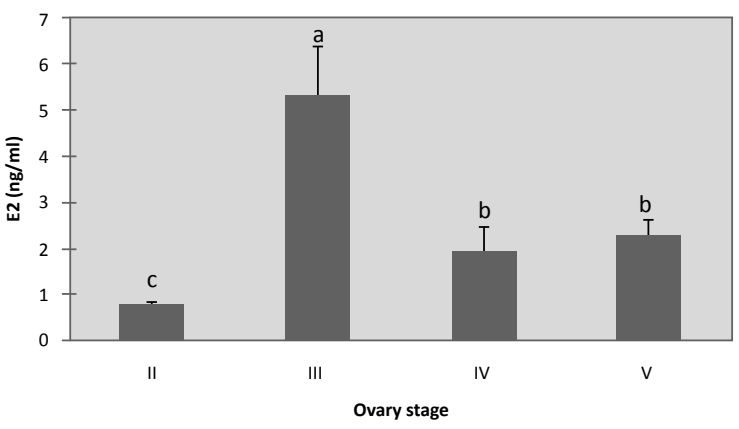

Figure 2: Changes in serum $17 \beta$ Estradiol (E2) levels by ovary stage of Persian sturgeon. Each value is mean $\pm S D$. Means with different letter subscripts are significantly different $(\mathrm{P}<0.05)$.

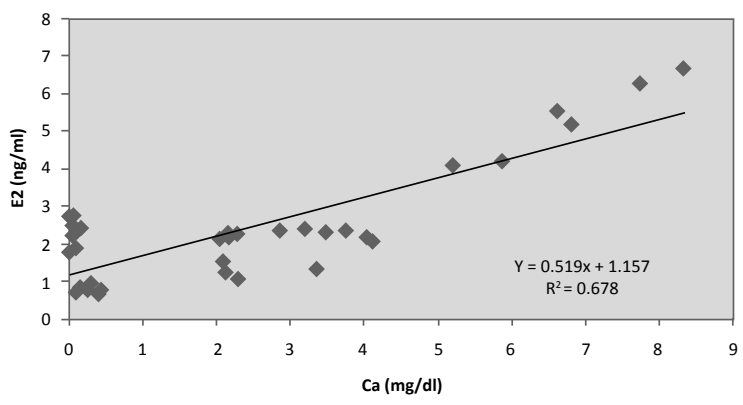

Figure 3: Relationship between total calcium (Ca) and $17 \beta$ Estradiol (E2) throughout ovary development of Persian sturgeon.

of calcium were observed in $\mathrm{V}$ and stage II females and these values did not differ significantly between stage II and $\mathrm{V}(\mathrm{P}>0.05)$.

There was no significant correlation between E2 and calcium in stages II, IV and V (data not shown), but generally, the results show that there was a positive relationship between concentration of E2 and total calcium of serum (Figure $3, \mathrm{r}^{2}=0.6789, \mathrm{P}<0.01$ ).

\section{Discussion}

In the present study, correlation was found between serum calcium and E2 levels during ovary development in female Persian sturgeon. Seasonal variation in serum calcium and E2 levels was observed, associated with ovarian stage and in agreement with earlier observations [11,18-21]. Serum E2 does not increase during the spawning (Figure 2). It increases during stage III (vitellogeniesis). Serum concentration of estrogen increase during phase III and varies consistently with the natural reproductive cycle [19,22-24]. The increase of estrogen secretion results in a rise of serum calcium during ovarian maturation. GTH-I circulate in the blood and upon reaching the ovaries, stimulates the follicle cells to synthesize E2, which is then released into the blood. E2 diffuses across the membrane of liver cells and binds to the estrogen receptors, resulting in initiation of transcription and translation of VTG [25]. Increasing E2 concentrations during oogenesis indirectly caused an increase in calcium levels in female shovelnose sturgeon because E2 simulates the liver to produce VTG [24].

Fleming et al. [11], Ho and Vanstone [26] and Woodhead [27] detected increased serum calcium levels in female fish after the administration of E2. Enhanced secretion of estrogen during the sexual maturation of females increases the serum calcium level [28]. Collectively, these results are in agreement with our work, as increased 
Citation: Hosseinzadeh M, Imanpoor MR, Shabani A, Nekoubin H (2013) Seasonal Changes in Serum Calcium and 17ß-Estradiol Levels in Persian Sturgeon, Acipenser persicus. J Aquac Res Development 4:159 doi:10.4172/2155-9546.1000159

secretion of E2 during stage III is correlated with increased serum calcium concentration.

Several authors have correlated the increased blood calcium content with ovarian maturation [28,29]. E2 has been shown to stimulate hepatic formation of VTG, increase serum VTG levels, and increase protein-bound fraction of plasma calcium levels [20].

Female bester Huso husoxAcipneser ruthenus, stellate, and Atlantic sturgeon exhibit peak E2 concentrations when gravid and E2 concentrations drop significantly following ovulation [5,16,25]. Concomitant increases in plasma calcium and VTG concentration following estrogenic stimulation have been reported previously in salmonid fish [15].

In the present study, relationship was observed between the total calcium level in blood serum and ovarian maturation of Persian sturgeon. These results indicate that the gonads play an important role in the calcium regulatory system of females. The seasonal peaks in serum E2 and calcium concentrations occur during stage III, not at ovulation. Additionally calcium appears to be at its lowest level in stage V (Figure 1). Therefore, seasonal fluctuations in serum E2 and calcium concentrations in female Persian sturgeon may be indicative of ovulation timing.

Also, there was significantly correlation between serum calcium and E2 during stage III, therefore both of these values can be utilized to identify vitellogenic females in sturgeon broodstocks.

\section{Acknowledgements}

The authors are grateful to staffs of Shahid Marjani sturgeon Propagation Center in Gorgan, Iran, for helping our study. And we would like to thank Mr. Seyed Mostafa Aghilinejhad for the help.

\section{References}

1. Berg LS (1948) Freshwater fishes of the USSR and adjacent countries. Nauka Publication, Moscow

2. Kiabi BH, Abdoli A, Naderi M (1999) Status of the fish fauna in the South Caspian Basin of Iran. Zoology in the Middle East 18: 57-65.

3. Webb MAH, Feist GW, Foster EP, Schreck CB, Fitzpatrick MS (2002) Potential classification of sex and stage of gonadal maturity of wild white sturgeon using blood plasma indicators. Transactions of the American Fisheries Society 131 : 132-142.

4. Doroshov SI, Moberg GP, Van Eenennaam JP (2002) Observations on the reproductive cycle of cultured white sturgeon, Acipenser transmontanus. Sturgeon Biodiversity and Conservation 17: 265-278.

5. Amiri BM, Maebayashi M, Adachi S, Yamauchi K (1996) Testicular development and serum sex steroid profiles during the annual sexual cycle of the male sturgeon hybrid the bester. J Fish Biol 48: 1039-1050.

6. Barannikova IA, Bayunova LV, Semenkova TB (2004) Serum levels of testosterone, 11-ketotestosterone and oestradiol-17 $\beta$ in three species of sturgeon during gonadal development and final maturation induced by hormonal treatment. J Fish Biol 64: 1330-1338.

7. Mommsen TP, Walsh PJ (1988) 5 Vitellogenesis and oocyte assembly. Fish Physiology 11: 347-406.

8. Silversand C, Haux C (1995) Fatty acid composition of vitellogenin from four teleost species. Journal of Comparative Physiology 164: 593-599.

9. Guerreiro PM, Fuentes J, Canario AV, Power DM (2002) Calcium balance in sea bream (Sparus aurata): the effect of oestradiol-17beta. J Endocrinol 173: 377-385.

10. Bailey RE (1957) The Effect of Estradiol on Serum Calcium, Phosphorus, and Protein of Goldfish. J Exp Zool 136: 455-469.

11. Fleming WR, Stanley JG, Meier AH (1964) Seasonal Effects of External Calcium, Estradiol, and Acth on the Serum Calcium and Sodium Levels of Fundulus Kansae. Gen Comp Endocrinol 15: 61-67.
12. Björnsson BT, Haux C, Bern HA, Deftos LJ (1989) 17 beta-estradiol increases plasma calcitonin levels in salmonid fish. Endocrinology 125: 1754-1760.

13. Björnsson BT, Haux C (1985) Distribution of calcium, magnesium and inorganic phosphate in plasma of estradiol-17 $\beta$ treated rainbow trout. J Compar Physio B 155: 347-352.

14. Woodhead AD, Woodhead PMJ (1965) Seasonal changes in the physiology of the Barents Sea cod, Gadus morhua L., in relation to its environment. I. Endocrine changes particularity affecting migration and maturation. International Commission for the Northwest Atlantic Fisheries Special Publication 6: 691715

15. Carragher JF, Sumpter JP (1991) T The mobilization of calcium from calcified tissues of rainbow trout (Oncorhynchus mykiss) induced to synthesize vitellogenin. Comparative Biochemistry and Physiology Part A: Physiology 99: 169-172.

16. Amiri BM, Maebayashi M, Hara A, Adachi S, Yamauchi K (1996) Ovarian development and serum sex steroid and vitellogenin profiles in the female cultured sturgeon hybrid, the bester. J Fish Biol 48: 1164-1178.

17. Semenkova T, Barannikova I, Kime DE, McAllister BG, Bayunova L, et al. (2002) Sex steroid profiles in female and male stellate sturgeon (Acipenser stellatus Pallas) during final maturation induced by hormonal treatment. Journal of Applied Ichthyology 18: 375-381.

18. Srivastav SP, Swarup K, Srivastava S (1985) Seasonal changes in the serum calcium level and prolactin cells of Clarias batrachus in relation to the reproductive cycle. Ann Endocrinol (Paris) 46: 426-429.

19. Whitehead C, Bromage NR, Forster JRM, (1985) Seasonal changes in reproductive function of the rainbow trout (Salmo gairdneri). J Fish Biol 12 601-608.

20. Woodhead PMJ (1968) Seasonal changes in the calcium content of the blood of arctic cod. Journal of Marine Biological Association of the United Kingdom 48: 81-91.

21. Björnsson BT, Haux C, Förlin L, Deftos LJ (1986) The involvement of calcitonin in the reproductive physiology of the rainbow trout. J Endocrinol 108: 17-23.

22. Crim LW, Idler DR (1978) Plasma gonadotropin, estradiol, and vitellogenin and gonad phosvitin levels in relation to the seasonal reproductive cycles of female brown trout. Ann Biol Anim Bioch Biophys 18: 1001-1005.

23. Norberg B, Björnsson BT, Brown CL, Wichardt UP, Deftos LJ, et al. (1989) Changes in plasma vitellogenin, sex steroids, calcitonin, and thyroid hormones related to sexual maturation in female brown trout (Salmo trutta). Gen Comp Endocrinol 75: 316-326.

24. Mol K, Byamungu N, Cuisset B, Yaron Z, Ofir M, et al. (1994) Hormonal profile of growing male and female diploids and triploids of the blue tilapia,Oreochromis aureus, reared in intensive culture. Fish Physiology and Biochemistry 13: 209218.

25. Barannikova IA, Dyubin VP, Bayunova LV, Semenkova TB (2002) Steroids in the control of reproductive function in fish. Neurosci Behav Physiol 32: 141-148.

26. Ho FCW, Vanstone WE (1961) Effect of Estradiol Monobenzoate on some Serum Constituents of Maturing Sockeye Salmon (Oncorhynchus nerka). Journal of the Fisheries Research Board of Canada 18: 859-864.

27. Woodhead PM (1969) Effects of oestradiol and thyroxine upon the plasma calcium content of a shark, Scyliorhinus canicula. Gen Comp Endocrinol 13 310-312.

28. Swarup K, Srivastav SP, Srivastav AK (1986) Seasonal changes in the structure and behaviour of Stannius corpuscles and serum calcium level of Clarias batrachus in relation to the reproductive cycle. Zoologischer Anzeiger 217: 402-408.

29. Singh S, Srivastav AK (1990) Changes in the serum calcium and phosphate levels in relation to the annual reproductive cycle of the freshwater catfish, Heteropneustes fossilis. Boletim de Physiologie Animale 14: 81-86. 